Konstantin Shevchenko-Bitenskyi,

PhD (Candidate of Medical Sciences),

State institution "South Ukrainian National Pedagogical University named after K. D. Ushynsky”, 26, Staroportofrankovskaya Str., Odessa, Ukraine

Valeriy Bitenskyi,

Doctor of Medical Sciences, professor, corresponding member of the National Academy of Medical Sciences of Ukraine, State institution "South Ukrainian National Pedagogical University named after K. D. Ushynsky”, 26, Staroportofrankovskaya Str., Odessa, Ukraine

\title{
INNOVATIVE DIRECTION IN THEATMENT OF MENTAL ILLNESS USING SYNERGETIC EFFECTS OF BRAIN TISSUES
}

All etiopathogenetic concepts in modern medicine are based on causal, linear and deterministic relationships. The diseases with an unknown etiology obviously do not have pathogenesis and in relation to that there is no adequate therapy to date. Psychopharmacologists create pharma drugs for the treatment of mental illness based on the same linear principles. However, since the 60s of the 20th century, thanks to the discoveries of many great scientists (for example, Ilya Prigozhin -Nobel Laureate), ideas about nonlinear systems in the nature of the Earth and Human began to develop (Haken, 2007). In particular, most of the serious mental illnesses are classified as open, non-linear, unstable, selforganizing systems. It is obviously that these systems should be changed under the influence of "throwing" into their chaotic structure of a disturbing agent, creating new systems instead of painful ones on the basis of adaptive effects of pre- and postconditioning (PreC; PostC). We have examined and carried out a therapy with a "non-linear" complex of effects of cerebral hypo- and hyperthermia, inhalation of xenon $(\mathrm{Xe})$ and nitrous oxide $\left(\mathrm{N}_{2} \mathrm{O}\right)$ using intravenous induction and inhalation of valproate (normotimic effect) in 85 patients with obsessive-compulsive disorders. A statistically significant ( $p>0.001)$ therapeutic effect has been obtained in almost $100 \%(92 \%)$ of patients.

Keywords: Synergetics, non-linear self-organizing open system, dissipative structure, fractals, preconditioning, chaos, obsessive-compulsive disorder.

Подано до редакиіï 19.06.2020

UDC: $373.2: 81 ' 24(560)$

DOI: https://doi.org/10.24195/2414-4665-2020-2-9

\begin{abstract}
Abdülkadir Kabadayı,
PhD (Candidate of Pedagogical Sciences), associate professor, Dr., A.K. Faculty of Education, Department of Basic Education, Necmettin Erbakan University, Meram Kampüsü, Meram Yeniyol, 42090, Meram Yeniyol, Konya, Turkey
\end{abstract}

\section{ANALYZING THE TURKISH PRESCHOOLERS' NATIVE LANGUAGE USE IN RESPECT OF THE CONTENT \& FUNCTION WORDS}

Human beings come to the World by the innate capacity of learning and using the language in the society they were born. Learning any language is the most important gift given by the God to the human beings. Any child should have some difficulties or hard experience in the process of acquiring his / her mother tongue. Therefore, it is inevitable for a child to make some mistakes in the acquisition process. Content and the function words in any language are the language elements exposed to be discussed. Less is known about differences in how content and function words are produced. Therefore, it is highly important to analyze the situation of the children's use of the content and function words in the process of their language use. The purpose of this research is to analyze the content \& function words the preschoolers use in acquiring their native language, Turkish. As it is a longitudinal study Qualitative research method was used to collect the study data. The aim is to reveal to what rate and to what extend the children use content \& function words most during their free time activities, language activities, nature and science activities, and drama activities etc. 76 children participated in the research. 33 of them were female and the 43 of them were male. The participants were 5 and 6 years old. They are still dwelling in Konya and Manisa the districts of Turkey. The findings were classified under linguistics categories as nouns, verbs, adjectives, pronoun, prepositions, prefix, suffix and affixes etc. In this research, 5-year-old preschoolers used 30 percent of the language units in the CONTENT words frame while 6-year-old preschoolers used 70 percent of the language units in the FUNCTION words frame. Males used 54 percent and female used 46 percent of the NOUNS including common, proper noun, abstract, concrete, singular and 
plural nouns. 5-year-old preschoolers used 27 percent of the VERBS while 6-year-old preschoolers used 73 percent of them CONTENT words. In this research, males used 58 percent and female used 42 percent of the ADJECTIVES in CONTENT words. In this research, males used 47 percent and female used 53 percent of the PRONOUNS including personal, denotative, interrogative and transformative pronouns in FUNCTION words. 5-year-old preschoolers used 25 percent of the ADVERBS while 6-year-old preschoolers used 75 percent of the ADVERBS in CONTENT words. In this research, males used 30 percent and female used 70 percent of the PREPOSITIONS including in FUNCTION words. Males used 48 percent and female used 52 percent of the CONJUCTIONS in FUNCTION words. Males used 35 percent and female used 65 percent of the GERUNDS in CONTENT words. 5-year-old preschoolers used 30 percent of the STRUCTURE OF VERBS while 6-year-old preschoolers used 70 percent of the STRUCTURE OF VERBS comprising transitive, intransitive, causative, active, passive and transformative structures in CONTENT words. Males used 48 percent and female used 52 percent of the INFLACTIONALS in FUNCTION words. As a last remark, some recommendations will be made to the teachers and the parents of the preschoolers about the descriptive result of the study.

Keywords: Qualitative, Content, Longitudinal, Konya, Manisa, Preschool institutions, Function words.

\section{Introduction and the current state of the issue}

Learning any language is the most important gift given by the God to the human beings. Any child should have some difficulties or hard experience in the process of acquiring his / her mother tongue. The children have ability to come over any difficulty they met how complex the language they are learning. They can construct the language and linguistics units naturally even though they are not taught. Therefore, it is inevitable for a child to make some mistakes in the acquisition process in any linguistics elements of any languages in the world as they pass the same stages in any languages in any country of the world. Garrett $(1975,1980)$ pointed out that content and function words should be analyzed in pronunciation, production and comprehension stages. Word exchanges are very largely limited to content words. Function words, however, are common in shifts, a positional misplacement of a word. In addition, sound exchanges are overwhelmingly restricted to content words. Processing of function words is impaired but content words are largely spared in agrammatic (Broca's) aphasia, (Goodglass, \& Menn, 1985; Caramazza, \& Berndt, 1985). There are also suggestions that there may be differences in the effects of frequency and predictability in the processing of content and function words, although only from studies of comprehension. Segalowitz and Lane (2000) found a strong frequency effect for content words, possibly diminished for more frequent words. Segalowitz and Lane (2000) also found that function words were in general accessed faster than content words. Herron and Bates (1997) found that frequency and predictability may affect access times of content and function words differently in comprehension. The general issue of whether observed differences between content and function words are due to an intrinsic difference or to differences in their form and function have long vexed studies of the role of lexical class in speech processing. Stemberger, Segalowitz and Lane (2000) mentioned that function words are more frequent, more predictable, have shorter phonological forms, are less likely to be prosaically prominent, and exhibit more idiosyncratic form variation than content words. The distinction between content and function words has been demonstrated on many dimensions of human languages. Content words, such as nouns, verbs, adjectives, and adverbs, are open-class words, which mean they belong to a language class which always accepts new additions. In contrast, the functional elements of language, including auxiliaries, determiners, complementizes, and some prepositions, are closed class words, meaning languages do not easily admit changes to this set. This restricted nature of the class of function words is a consequence of its role in encoding grammatical structure. Furthermore, its restricted nature is 28 one of the properties that makes it useful in classifying content words; noting co-occurrence relationships between function words and content words is a more efficient way to classify content words than by noting their co-occurrences with other content words (Gleitman, Gleitman, Landau, and Wanner, 1988). Function words have a low type count, but a high token frequency. Although some categories are language-specific (for example, Mandarin Chinese has classifiers while English does not), it has been argued that the basic content-function distinction is a universal property of languages (Morgan, Shi, and Allopenna, 1996; Shi, 2005).

\section{Problem Statement}

Content and the function words in any language are the language elements exposed to be discussed. Less is known about differences in how content and function words are produced. The widely held presumption that they are produced differently rests mainly on evidence that they participate in different kinds of speech errors. It is highly important to analyze the situation of the children's use of the content and function words in the process of their language use.

\section{Purpose of the Study}

This study was conducted to analyze the content \& function words the preschoolers use in acquiring their native language, Turkish.

\section{Materials and Methods}

In this study, descriptive research method was used to explain the study data. 76 children participated in the research. 33 of them were female and the 43 of them were male. They were chosen randomly from Konya and Manisa districts' preschool institutions. The participants were 5 and 6 years old. When the research was carried out they were dwelling in Konya and Manisa developed districts of Turkey.

Research Questions was to reveal to what rate and to what extend the children use content \& function words most during their free time; language; nature \& science; and drama activities. 
Description and categorization of the content words

\begin{tabular}{|c|c|c|}
\hline $\begin{array}{l}\text { Category } \\
\text { nouns }\end{array}$ & $\begin{array}{c}\text { Description } \\
\text { people, places, things, and } \\
\text { ideas }\end{array}$ & \begin{tabular}{c} 
Patty, Seattle, cars, happiness \\
\hline main verbs
\end{tabular} \\
\hline $\begin{array}{c}\text { adjectives } \\
\text { cept adverbs } \\
\text { of frequency) }\end{array}$ & words that describe nouns & ran, swim, thinks \\
\hline question & words that describe nouns & calmly, quickly, carefully \\
\hline words & words that denote a question & \\
\hline negatives & words that negate & who, what, where, when, \\
\hline
\end{tabular}

Table 1.2

Description and categorization of the function words

\begin{tabular}{|l|}
\hline Category \\
\hline auxiliary \\
verbs \\
\hline prepositions \\
\hline conjunctions \\
\hline determiners \\
\hline pronouns
\end{tabular}

Description
verbs that support the main verbs
words that tell relation to other
words
words that tie clauses together
words that give detail to nouns
words that replace nouns

Examples

am, are, has, could, should

at, on, to, near

and, so, but, however

a, an, the, some, any

I, it, we, they, he, she

\section{Results}

The research was done during preschoolers' free time; language; nature \& science; and drama activities. Their talk and speech was recorded by video and some parts of their speeches were noted by the researchers. Later, they were transcribed and analyzed, sort out and categorized in the frame of content $\&$ function words.

Table 2.1

Participants' production of “CONTENT \& FUNCTION" Words in respect of "gender"

\begin{tabular}{|c|c|c|c|c|c|c|}
\hline \multicolumn{2}{|c|}{ Content words } & & \multicolumn{2}{c|}{ Function } \\
\hline \multicolumn{2}{|c|}{ Female } & \multicolumn{3}{|c|}{ Male } & & Female \\
\hline
\end{tabular}


In this research, males produced 53 percent and female used 47 percent of the language units in the CONTENT words frame while males produced 48 percent and female used 52 percent of the language units in the FUNCTION words frame. Bell at all. (2009) investigated whether the speaker was a man or woman mainly influenced durations through a strong interaction with rate of speech, with men speaking at faster rates in content and function words.

Table 2.2

Participants' production of "CONTENT \& FUNCTION" Words in respect of "Age

\begin{tabular}{|c|c|c|c|c|c|c|c|}
\hline & \multicolumn{3}{|c|}{ Content words } & \multicolumn{3}{|c|}{ Function } & \\
\hline & 5 & \multicolumn{2}{|c|}{6 Years old } & \multicolumn{2}{|c|}{5 Years old } & 6 Years old & \\
\hline f & $\%$ & $\mathrm{f}$ & $\%$ & $\mathrm{f}$ & $\%$ & $\mathrm{f}$ & $\%$ \\
\hline 193 & $\% 28$ & 724 & $\% 72$ & 1172 & $\% 26$ & 3374 & $\% 74$ \\
\hline
\end{tabular}

5-year-old preschoolers used 30 percent of the language units in the CONTENT words frame while 6-yearold preschoolers used 70 percent of the language units in the FUNCTION words frame. Bell, et al. (2009) found that the age of the speaker also affected word durations in content and function words and emphasized that older speakers have longer durations.

Table 2.3

Participants" production of "NOUNS" in respect of "gender and age" in Content words

\begin{tabular}{|c|c|c|c|c|c|c|c|}
\hline \multicolumn{4}{|c|}{ Sex } & & \multicolumn{3}{|c|}{ Age } \\
\hline \multicolumn{2}{|c|}{ Female } & \multicolumn{2}{|c|}{ Male } & \multicolumn{2}{|c|}{5 years old } & \multicolumn{2}{|c|}{6 years old } \\
\hline $\mathbf{F}$ & $\%$ & $\mathrm{f}$ & $\%$ & $\mathrm{f}$ & $\%$ & $\mathrm{f}$ & $\%$ \\
\hline 260 & $\% 46$ & 1500 & 54 & 758 & $\% 26$ & 2145 & $\% 74$ \\
\hline
\end{tabular}

In this research, males used 54 percent and female used 46 percent of the NOUNS including common, proper noun, abstract, concrete, singular and plural nouns, 5- year-old preschoolers used 26 percent of the NOUNS while 6-year-old preschoolers used 74 percent of them.

Table 2.4

Participants' production of "VERBS" in respect of "gender and age" in Content words

\begin{tabular}{|c|c|c|c|c|c|c|c|}
\hline \multicolumn{4}{|c|}{ Sex } & \multicolumn{4}{|c|}{ Age } \\
\hline \multicolumn{2}{|c|}{ Female } & \multicolumn{2}{|c|}{ Male } & \multicolumn{2}{|c|}{5 years old } & \multicolumn{2}{|c|}{6 years old } \\
\hline F & $\%$ & $\mathrm{f}$ & $\%$ & $\mathrm{f}$ & $\%$ & $\mathrm{f}$ & $\%$ \\
\hline 605 & $\% 42$ & 824 & $\% 58$ & 465 & $\% 27$ & 1260 & $\% 73$ \\
\hline
\end{tabular}

In this research, males used 58 percent and female used 42 percent of the VERBS including declaring action, state, simple, compound and derived according to their meanings, tenses and structure in CONTENT words. 5-year-old preschoolers used 27 percent of the VERBS while 6-year-old preschoolers used 73 percent of them CONTENT words. 
Participants' production of “ADJECTIVES" in respect of "gender and age” in Content words

\begin{tabular}{|c|c|c|c|c|c|c|c|}
\hline \multicolumn{4}{|c|}{ Sex } & \multicolumn{4}{|c|}{ Age } \\
\hline \multicolumn{2}{|c|}{ Female } & \multicolumn{2}{|c|}{ Male } & \multicolumn{2}{|c|}{5 years old } & \multicolumn{2}{|c|}{6 years old } \\
\hline $\mathbf{F}$ & $\%$ & $\mathrm{f}$ & $\%$ & $f$ & $\%$ & $\mathrm{f}$ & $\%$ \\
\hline 50 & $\% 42$ & 70 & $\% 58$ & 28 & $\% 23$ & 92 & $\% 77$ \\
\hline
\end{tabular}

In this research, males used 58 percent and female used 42 percent of the ADJECTIVES in CONTENT words. 5-year-old preschoolers used 23 percent of the
ADJECTIVES including attributive, denotative adjectives while 6-year-old preschoolers used 77 percent of them CONTENT words.

Participants' production of "PRONOUNS" in respect of "gender and age" in Function words

\begin{tabular}{|c|c|c|c|c|c|c|c|}
\hline \multicolumn{4}{|c|}{ Sex } & \multicolumn{4}{|c|}{ Age } \\
\hline & Female & Male & & $5 y$ & & 6 ye & \\
\hline F & $\%$ & $\mathrm{f}$ & $\%$ & f & $\%$ & $\mathrm{f}$ & $\%$ \\
\hline 170 & $\% 53$ & 149 & $\% 47$ & 82 & 25 & 247 & $\% 75$ \\
\hline
\end{tabular}

In this research, males used 47 percent and female used 53 percent of the PRONOUNS including personal, denotative, interrogative and transformative pronouns in
FUNCTION words.5-year-old preschoolers used 23 percent of the PRONOUNS while 6-year-old preschoolers used 77 percent of them FUNCTION words

Participants' production of "ADVERBS" in respect of "gender and age" in Content words

\begin{tabular}{|l|l|l|l|l|l|l|l|}
\multicolumn{3}{|c|}{ Sex } & & \multicolumn{3}{c|}{ Age } \\
\hline Female & Male & 5 years old & 6 years old \\
\hline F & $\%$ & f & $\%$ & $\mathrm{f}$ & $\%$ & $\mathrm{f}$ & $\%$ \\
\hline 96 & $\% 53$ & 86 & $\% 47$ & 55 & $\% 25$ & 165 & $\% 75$ \\
\hline
\end{tabular}

In this research, males used 47 percent and female used 53 percent of the ADVERBS including stative, directive, interrogative adverbs in CONTENT words. 5- year-old preschoolers used 25 percent of the ADVERBS while 6-year-old preschoolers used 75 percent of the ADVERBS in CONTENT words.

Table 2.8

Participants' production of "PREPOSITIONS" in respect of "gender and age" in Function words

\begin{tabular}{|c|c|c|c|c|c|c|c|}
\hline \multicolumn{4}{|c|}{ Sex } & \multicolumn{4}{|c|}{ Age } \\
\hline & Female & \multicolumn{2}{|c|}{ Male } & \multicolumn{2}{|c|}{5 years old } & \multicolumn{2}{|c|}{6 years old } \\
\hline $\mathbf{F}$ & $\%$ & $\mathrm{f}$ & $\%$ & $\mathrm{f}$ & $\%$ & $\mathrm{f}$ & $\%$ \\
\hline 57 & $\% 70$ & 25 & $\% 30$ & 17 & $\% 20$ & 67 & $\% 80$ \\
\hline
\end{tabular}


In this research, males used 30 percent and female used 70 percent of the PREPOSITIONS including in FUNCTION words. 5-year-old preschoolers used 20 percent of the PRONOUNS while 6-year-old preschoolers used 80 percent of the PREPOSITIONS in FUNCTION words.

Table 2.9

Participants" production of "CONJUCTIONS" in respect of "gender and age" in Function words

\begin{tabular}{|c|c|c|c|c|c|c|c|}
\hline \multicolumn{4}{|c|}{ Sex } & \multicolumn{4}{|c|}{ Age } \\
\hline \multicolumn{2}{|c|}{ Female } & \multicolumn{2}{|c|}{ Male } & \multicolumn{2}{|c|}{5 years old } & \multicolumn{2}{|c|}{6 years old } \\
\hline $\mathbf{F}$ & $\%$ & $f$ & $\%$ & $\mathrm{f}$ & $\%$ & $\mathrm{f}$ & $\%$ \\
\hline 152 & $\% 52$ & 91 & $\% 48$ & 62 & $\% 29$ & 155 & $\% 71$ \\
\hline
\end{tabular}

In this research, males used 48 percent and female used 52 percent of the CONJUCTIONS in FUNCTION words. 5-year-old preschoolers used 29 percent of the
PRONOUNS while 6-year-old preschoolers used 71 percent of the PROPOSITIONS in FUNCTION words.

Table 2.10

Participants' production of “GERUNDS" in respect of "gender and age" in Content words

\begin{tabular}{|c|c|c|c|c|c|c|c|}
\hline \multicolumn{4}{|c|}{ Sex } & \multicolumn{4}{|c|}{ Age } \\
\hline \multicolumn{2}{|c|}{ Female } & \multicolumn{2}{|c|}{ Male } & 5 years old & \multicolumn{3}{|c|}{6 years old } \\
\hline $\mathbf{F}$ & $\%$ & $\mathrm{f}$ & $\%$ & $\mathrm{f}$ & $\%$ & f & $\%$ \\
\hline 42 & $\% 65$ & 23 & $\% 35$ & 17 & $\% 25$ & 52 & $\% 75$ \\
\hline
\end{tabular}

In this research, males used 35 percent and female used 65 percent of the GERUNDS in CONTENT words. 5-year-old preschoolers used 25 percent of the GER-
UNDS while 6-year-old preschoolers used 75 percent of the GERUNDS in CONTENT words.

Table 2.11

Participants' production of "AUXILARY” in respect of "gender and age" in Function words

\begin{tabular}{|c|c|c|c|c|c|c|c|}
\hline \multicolumn{4}{|c|}{ Sex } & \multicolumn{4}{|c|}{ Age } \\
\hline \multicolumn{2}{|c|}{ Female } & \multicolumn{2}{|c|}{ Male } & \multicolumn{2}{|c|}{5 years old } & \multicolumn{2}{|c|}{6 years old } \\
\hline $\mathbf{F}$ & $\%$ & $\mathrm{f}$ & $\%$ & $\mathrm{f}$ & $\%$ & $\mathrm{f}$ & $\%$ \\
\hline 142 & $\% 42$ & 198 & $\% 58$ & 96 & $\% 25$ & 285 & $\% 75$ \\
\hline
\end{tabular}

In this research, males used 58 percent and female used 42 percent of the AUXILARIES including present, past, past perfect conditional forms of auxiliary verbs in FUNCTION words. 5-year-old preschoolers used 25 percent of the AUXILARIES while 6-year-old preschoolers used 75 percent of the AUXILARIES in FUNCTION words

Table 2.12

Participants" production of "STRUCTURE of VERBS" in respect of "gender and age" in Content words

\begin{tabular}{|c|c|c|c|c|c|c|c|}
\hline \multicolumn{4}{|c|}{ Sex } & \multicolumn{4}{|c|}{ Age } \\
\hline & & & & \multicolumn{2}{|c|}{5 years old } & \multicolumn{2}{|c|}{6 years old } \\
\hline $\mathbf{F}$ & $\%$ & $f$ & $\%$ & $\mathrm{f}$ & $\%$ & $\mathrm{f}$ & $\%$ \\
\hline 385 & $\% 44$ & 490 & $\% 56$ & 268 & $\% 30$ & 620 & $\% 70$ \\
\hline
\end{tabular}


In this research, males used 56 percent and female used 44 percent of the STRUCTURE OF VERBS in CONTENT words. 5-year-old preschoolers used 30 percent of the STRUCTURE OF VERBS while 6-year-old preschoolers used 70 percent of the STRUCTURE OF VERBS comprising transitive, intransitive, causative, active, passive and transformative structures in $\mathrm{CON}$ TENT words.

Table 2.13

Participants' production of "MORPHEMES" in respect of "gender and age" in Content words

\begin{tabular}{|c|c|c|c|c|c|c|c|}
\hline & \multicolumn{3}{|c|}{ Sex } & \multicolumn{3}{c|}{ Age } \\
\hline \multicolumn{2}{|c|}{ Female } & \multicolumn{2}{|c|}{ Male } & \multicolumn{2}{c|}{ 5 years old } & \multicolumn{3}{c|}{ 6 years old } \\
\hline $\mathbf{F}$ & $\%$ & $\mathrm{f}$ & $\%$ & $\mathrm{f}$ & $\%$ & $\mathrm{f}$ & $\%$ \\
\hline $\mathbf{6 7 6}$ & $\% 55$ & 550 & $\% 45$ & 602 & $\% 30$ & 1390 & $\%$ \\
\hline
\end{tabular}

In this research, males used 45 percent and female used 55 percent of MORPHEMES indicating simple, compound, derived morphemes in CONTENT words. 5- year-old preschoolers used 30 percent of the MORPHEMES while 6-year-old preschoolers used 70 percent of the MORPHEMES in CONTENT words.

Table 2.14

\section{Participants' production of "INFLECTIONALS" in respect of "gender and age" in Function words}

\begin{tabular}{|c|c|c|c|c|c|c|c|}
\hline \multicolumn{4}{|c|}{ Sex } & \multicolumn{4}{|c|}{ Age } \\
\hline \multicolumn{2}{|c|}{ Female } & \multicolumn{2}{|c|}{ Male } & \multicolumn{2}{|c|}{5 years old } & \multicolumn{2}{|c|}{6 years old } \\
\hline $\mathbf{F}$ & $\%$ & $\mathrm{f}$ & $\%$ & $\mathrm{f}$ & $\%$ & $\mathrm{f}$ & $\%$ \\
\hline 850 & $\% 52$ & 787 & $\% 48$ & 780 & $\% 25$ & 2300 & $\% 75$ \\
\hline
\end{tabular}

In this research, males used 48 percent and female used 52 percent of the INFLACTIONALS in FUNCTION words. 5-year-old preschoolers used 25 percent of the INFLACTIONALS including possessive, state, comple- mentary, interrogative, plurality, modals, personal and negative inflectional while 6-year-old preschoolers used 75 percent of the INFLACTIONALS in FUNCTION words.

Table 2.15

\begin{tabular}{|c|c|c|c|c|c|c|c|}
\hline \multicolumn{4}{|c|}{ Sex } & \multicolumn{4}{|c|}{ Age } \\
\hline \multicolumn{2}{|c|}{ Female } & \multicolumn{2}{|c|}{ Male } & \multicolumn{2}{|c|}{5 years old } & \multicolumn{2}{|c|}{6 years old } \\
\hline $\mathbf{F}$ & $\%$ & $\mathrm{f}$ & $\%$ & $f$ & $\%$ & $\mathrm{f}$ & $\%$ \\
\hline 162 & $\% 52$ & 150 & $\% 48$ & 135 & $\% 30$ & 320 & $\% 70$ \\
\hline
\end{tabular}

In this research, males used 48 percent and female used 52 percent of the DERIVATIONALS compromising derivationally derived from noun to noun, from noun to verb, from verb to verb, from verb to noun in FUNCTION words. 5-year-old preschoolers used 30 percent of the DERIVATIONALS while 6-year-old preschoolers used 70 percent of the DERIVATIONALS in FUNCTION words

\section{Conclusion}

As a result of the study, males used more language units related to CONTENT words than females did. As for function words, females produced more language units related to FUNCTION words than males did. The review of the literature revealed unique basic differences inherent in each of the two word classes. Although learnability has been applied to a number of other concepts, no one has yet applied it to this aspect of linguistic structure content and function words. As was also noted in the literature, function words are generally acknowledged to be more difficult to learn than are content words (Jefferson, 1969; Weaver, 1964). Research literature also indicated that the consideration of socioeconomic levels in studying the problem of differences in function and content words is important. Thomas (1962) found out that low socioeco- 
nomic subjects scored significantly poorer on the S-R. This was reflected in both the analysis of the data and in the fact that almost $20 \%$ of the low socioeconomic subjects failed to complete the task. Furthermore, it was suggested justifying further investigation into such areas as "Learnability", the influence of socio-economic level on learning, and the use of oral context in initial learning. Furthermore, Lapointe and Dell (1989) put forward that content words are accessed via network activation, filling slots in syntactic phrase structures. Consequently, at the level of lemma selection, content words are distinguished from function words. Even this weaker distinction was rejected by Stemberger (1985), who proposed that content and function words are accessed in the same way. Contrarily, Bell at all. (2009) pointed out that the men spoke faster rates in content and function words. As a result of the study, 6-year-old preschoolers produced more language units related to CONTENT words than 5-year-old preschoolers produced. As for FUNCTION words, 6year-old preschoolers produced more language units than 5 -year-old preschoolers in the FUNCTION words frame. Research on language acquisition has shown a different pattern for function words and content words (e.g., Brown and Hanlon, 1970), with function words typically missing in children's early production in many languages. These studies provide evidence from an area outside of acquisition research that function words and content words are processed differently (Shi, Gick, Kanwischer, \& Wilson,

\section{References}

1. Bell, A., Brenier, Jason M., Gregory, M., Girand, C., \& Jurafsky, D. (2009). Predictability Effects on Durations of Content and Function Words in Conversational English, Journal of Memory and Language, 60 , 92-111.

2. Brown, R., \& Hanlon, C. (1970). Derivational complexity and order of acquisition in child speech. In J.R. Hayes (Ed.), Cognition and the development of language. New York: Wiley.

3. Caramazza, A., \& Berndt, R. S. (1985). A multicomponent deficit view of agrammatic Broca's aphasia. In M. L. Kean (Ed.), Agrammatism (pp. 27-63). Orlando: Academic Press.

4. Garrett, M. F. (1975). The analysis of sentence production. In Bower, G. H. (Ed.), The psychology of learning and motivation: Advances in research and theory, 9, 133-177. London: Academic Press.

5. Garrett, M. F. (1980). Levels of processing in sentence production. In Bower, G. H. (Ed.), Language production, 1, 177-220.

6. Goodglass, H., \& L. Menn. (1985). Is agrammatism a unitary phenomenon? In M.L. Kean (Ed.), Agrammatism (pp. 1-26). Orlando: Academic Press.

7. Gerken, L. A., Landau, B., \& Remez, R. E. (1990). Function morphemes in young children's speech perception and production. Developmental Psychology, 27, 204-216.

8. Gerken, L. A., \& McIntosh, B. J. (1993). The interplay of function morphemes and prosody in early language. Developmental Psychology, 29, 448-457.

9. Gleitman, L., Gleitman, H., Landau, B., \& Wanner, E. (1988). Where learning begins: initial repre-
2005). When infants begin to recognize the function words of their own language, they may start compiling them into list. From such a list they can begin to notice co-occurrence patterns, for example, that function words often appear adjacently or in fairly regular distributional relationship to the other broad category of words, content words, and furthermore that certain function words only occur with certain content words. Indeed, research has established that young infants do recognize function words, even before they are able to produce them (Gerken, Landau, \& Remez, 1990; Gerken \& McIntosh 1993; Shady 1996; Shafer, Shucard, Shucard, \& Gerken, 1998; Santelmann, \& Jusczyk, 1998). For infants to address this problem, Shi (2005) has proposed that they may begin by making a rudimentary category distinction between function words and content words, based on the universal properties of these two basic word classes. Hence, these properties of function words available in the speech signal have been found to be roughly consistent across languages (Shi et al, 1998), which means that learners of many different languages may be able to use these properties in the same way at the same age.

The research should be carried out in national level with more great number of samples to build up the basement for the researchers. The research should also be done at cross-cultural levels to display the similarities and differences between the preschoolers in the production of CONTENT and FUNCTION words.

sentations for language learning. In F. J. Newmeyer, Linguistics, the Cambridge Survey, 3, 150-193. Cambridge: Cambridge University Press.

10. Herron, D. T., \& Bates, E. A. (1997). Sentential and acoustic factors in the recognition of open- and closed-class words. Journal of Memory and Language, 37, 217-239.

11. Jefferson, G. L. (1969) Lexical and structural items as predictors of readability for high and low ability readers. Unpublished Doctoral Dissertation, University of Georgia.

12. Lapointe, S. G., \& Dell, G. S. (1989). A synthesis of some recent work in sentence production. In G. N. Carlson \& M. K. Tanenhaus (Eds.), Linguistic structure in language processing (pp. 107-156). Dordrecht: Kluwer.

13. Morgan, J., Allopenna, P., \& Shi, R. (1996). Perceptual bases of rudimentary grammatical categories: Toward a broader conceptualization of bootstrapping. In J. Morgan and K. Demuth (Eds.).

14. Santelmann, L., \& Jusczyk, P. (1998). Sensitivity to discontinuous dependencies in language learners: Evidence for limitations in processing space. Cognition. 69(2), 105-134.

15. Segalowitz, S. J., \& Lane, K. C. (2000). Lexical access of function versus content words. Brain and Language, 75, 376-389.

16. Shafer, V. L., Shucard, D. W., Shucard, J. L., \& Gerken, L. A. (1998). An electrophysiological study of infants' sensitivity to the sound patterns of English speech. Journal of Speech, Language, and Hearing Research, 41(4), 874-886.

17. Shady, M. (1996). Infants' sensitivity to function morphemes. Ph.D. dissertation, State University of 
New York at Buffalo.

18. Shi, R., Gick, B., Kanwischer, D., \& Wilson, I. (2005). Frequency and category factors in the reduction and assimilation of function words: EPG and acoustic measures. Journal of Psycholinguistic Research, 34(4), 341-364.

19. Shi, R. (2005). Early syntactic categories in infants. In H. Cohen \& C. Lefebvre (Eds.), Handbook of categorization in cognitive science (pp. 481-495). Elsevier.

20. Shi, R., Morgan, J., \& Allopenna, P. (1998). Phonological and acoustic bases for earliest grammatical category assignment: a cross-linguistic perspective. Journal of Child Language, 25, 169-201.
21. Stemberger, J. P. (1985). An interactive activation model of language production. In A. Ellis (Ed.), Progress in the psychology of language (pp. 143-186). London: Erlbaum.

22. Thomas, D. R. (1962) Oral language sentence structure and vocabulary of kindergarten children living in low socio-economic urban areas. Ann Arbor: University Microfilms, Inc.

23. Weaver, W. W. (1964) On the psychology of reading, In E. L. Thurston \& L. E. Bather (Eds.), Thirteenth yearbook of the National reading conference. Milwaukee: National Reading Conference.

\section{АНАЛІЗ ВИКОРИСТАННЯ РІДНОЇ МОВИ ДОШКІЛЬНИКІВ ТУРЕЧЧИНИ У ВІДНОШЕННІ} САМОСТІЙНИХ ТА СЛУЖБОВИХ ЧАСТИН МОВИ

Люди приходять у Світ із вродженою здатністю до вивчення та використання мови у суспільстві, в якому вони народилися. Вивчення будь-якої мови - найважливіший подарунок, який Бог дає людям. Будь-яка дитина повинна мати певні труднощі або важкий досвід у процесі оволодіння рідною мовою. Таким чином, це неминуче для дитини робити деякі помилки в процесі оволодіння мовою. Самостійні та службові частини мови $\epsilon$ мовними елементами в будь-якій мові, що підлягають обговоренню. Менш відомо про відмінності утворення самостійних та службових частин мови. Таким чином, дуже важливо проаналізувати ситуацію використання дітьми самостійних та службових частин мови у процесі використання їх рідної мови. Мета цього дослідження - проаналізувати самостійні та службові частини мови, які дошкільники використовують в рідній турецькій мові. Оскільки це лонгітюдне дослідження, використовувався якісний метод для збору даних. Метою також $є$ виявлення з якою швидкістю та якою мірою діти найчастіше використовують самостійні та службові частини мови у вільний час, на мовних заняттях, під час природознавчої та драматичної діяльності тощо. У дослідженні взяли участь 76 дітей, 33 з них були дівчата, а 43 з них - хлопці. Учасникам було 5 та 6 років. Вони мешкають у м. Конья та м. Маніса, що знаходяться в районах Туреччини. Отримані результати були класифіковані за такими лінгвістичними категоріями як іменники, дієслова, прикметники, займенники, прийменники, префікс, суфікс та афікси тощо. У цьому дослідженні 5-річні дошкільники використовували $30 \%$ мовних одиниць САМОСТІЙНИХ частини мови, а 6-річні дошкільники використовували 70\% мовних одиниць СЛУЖБОВИХ частин мови. Хлопці вживали мовні одиниці, де $54 \%$, а у дівчат $46 \%$ - це ІМЕННИКИ, включаючи загальні, власні іменники, абстрактні, конкретні, іменники однини та множини; 5-річні дошкільники вживали 27\%, а 6-річні дошкільники - 73\% ДІССЛІВ, що відносяться до САМОСТІЙНИХ частин мови. У цьому дослідженні хлопці використовували $58 \%$, а дівчата - $42 \%$ ПРИКМЕТНИКІВ, які відносяться до САМОСТІЙНИХ ЧАСТИН МОВИ. У цьому дослідженні хлопці використовували 47\%, а дівчата - 53\% ЗАЙМЕННИКІВ, включаючи особові, вказівні, питальні та зворотні займенники, що відносяться до СЛУЖБОВИХ частин мови; 5-річні дошкільники вживали 25\% ПРИСЛІВНИКІВ, тоді як 6-річні дошкільники - 75\% ПРИСЛІВНИКІВ, які відносяться до САМОСТІЙНИХ ЧАСТИН МОВИ. У цьому дослідженні хлопці використовували $30 \%$, а дівчата - $70 \%$ ПРИЙМЕННИКІВ, що відносяться до СЛУЖБОВИХ частин мови. Хлопці використовували $48 \%$, а дівчата - 52\% СПОЛУЧНИКІВ, що відносяться до СЛУЖБОВИХ частин мови. Хлопці вживали $35 \%$, а дівчата - 65\% такої форми дієслова як ГЕРУНДІЙ, який відноситься до САМОСТЙНОЇ частини мови; 5-річні дошкільники використовували 30\% РІЗНИХ СТРУКТУР ДІЕСЛОВА, тоді як 6-річні дошкільники використовували 70\% РІЗНИХ СТРУКТУР ДІЄСЛОВА, що містять перехідні, неперехідні, причинно-наслідкові, активні, пасивні та інші структури, які відносяться до САМОСТІЙНИХ частин мови. Хлопці використовують $48 \%$, а дівчата - $52 \%$ СЛОВОЗМІН, що відносять до СЛУЖБОВИХ частин мови. Як останнє зауваження, педагогам та батькам дошкільників будуть надані деякі рекомендації щодо описового результату дослідження.

Ключові слова: якісний, самостійна частина мови, лонгітюдний, Конья, Маніса, дошкільні заклади, службова частина мови. 